ISSN : $2302-1590$

E-ISSN: $2460-190 \mathrm{X}$

ECONOMICA

Journal of Economic and Economic Education Vol.4 No.2 (258-268)

\title{
PENGARUH KOMPENSASI FINANSIAL DAN MOTIVASI KERJA GURU TERHADAP KINERJA GURU SMK NEGERI PARIWISATA DI KOTA PADANG
}

\author{
Yesmira Syamra \\ Dosen Program Studi Pendidikan Ekonomi STKIP- PGRI Sumbar \\ Jl. Gunung Pangilun No.1, Padang Sumatera Barat \\ Email: yesmira@ymail.com
}

submited: 2016.06.20 reviewed: 2016.07.01 accepted: 2016.07.01

http://dx.doi.org/10.22202/economica.2016.v4.i2.628

\begin{abstract}
The purpose of this research is to know : 1 ) the effect of financial compensation to the work motivation of teachers , 2) the effect of financial compensation to the performance of teachers , 3 ) the effect of work motivation on teacher performance and 4 ) the effect of financial compensation and motivation to work on teacher performance. The analytical method used in this research is quantitative method with data analysis using path analysis. Sampling method using the formula Slovin where the population in the study was a teacher SMK Padang City Tourism totaling 117 people and 90 people were taken as samples. Based on the results obtained conclusions : 1 ) There may influence financial compensation to the work motivation with the influence of financial compensation to the work motivation by $51 \%, 2$ ) there are significant financial compensation to performance either directly or indirectly, the influence of financial compensation directly is 11:02 \% whereas the effect of indirectly by $12: 23 \% 3$ ) there is the influence of work motivation on teacher performance in which the influence of work motivation on the live performance was $26.41 \%$, and 4 ) there are significant financial compensation and motivation to work on teacher performance
\end{abstract}

\begin{abstract}
Abstrak
Tujuan penelitian ini dilakukan adalah untuk mengetahui:1) pengaruh kompensasi finansial terhadap motivasi kerja guru, 2) pengaruh kompensasi finansial terhadap terhadap kinerja guru, 3) pengaruh motivasi kerja terhadap kinerja guru dan 4) pengaruh kompensasi finansial dan motivasi kerja terhadap kinerja guru. Metode analisis yang digunakan dalam penelitian ini adalah metode kuantitatif, dengan analisis data menggunakan analisis jalur. Metode penarikan sampel menggunakan rumus Slovin dimana populasi dalam penelitian adalah guru SMK Negeri Pariwisata di Kota Padang yang berjumlah 117 orang dan diambil sebanyak 90 orang sebagai sampel. Berdasarkan hasil penelitian diperoleh simpulan: 1) terdapat dapat pengaruh kompensasi finansial terhadap motivasi kerja dengan besarnya pengaruh kompensasi finansial terhadap motivasi kerja sebesar 51\%, 2) terdapat pengaruh kompensasi finansial terhadap kinerja baik secara langsung maupun tidak langsung, besarnya pengaruh kompensasi finansial secara langsung adalah $11.02 \%$ sedangkan pengaruh secara tidak langsung sebesar 12.23\% 3) terdapat pengaruh motivasi kerja terhadap kinerja guru dimana besarnya pengaruh motivasi kerja terhadap kinerja secara langsung adalah $26.41 \%$ dan 4) terdapat pengaruh kompensasi finansial dan motivasi kerja terhadap kinerja guru.

Keywords : Financial Compensation, Work Motivation, Teacher Performance
\end{abstract}

C2016 Prodi Pendidikan Ekonomi STKIP PGRI, Padang 


\section{PENDAHULUAN}

Sekolah kejuruan merupakan salah satu upaya pemerintah untuk meningkatkan sumberdaya manusia yang berkualitas dan memiliki keterampilan serta daya saing tinggi. Sekolah menegah kejuruan merupakan pendidikan menegah kejuruan yang mempersiapkan peserta didik untuk bekerja dalam bidang tertentu, dapat beradaptasi di lingkungan kerja, dapat melihat peluang kerja dan dapat megembangkan diri di kemudian hari agar menjadi tenaga kerja yang profesional.

Sesuai dengan bentuknya sekolah menengah kejuruan melaksanakan program-program pendidikan sesuai dengan jenis-jenis lapangan pekerjaan (Peraturan Pemerintah No. 29 Tahun 1990). Berdasarkan keputusan Direktur Jenderal Manajemen Pendidikan Dasar dan Menegah Departemen pendidikan Nasional nomor 251/C/KEP/MN/2008 tentang spectrum keahlian pendidikan menegah kejuruan. Dalam spectrum tersebut ada enam bidang studi keahlian yaitu: 1) teknologi dan rekayasa, 2) teknologi informasi dan komunikasi, 3) kesehatan, 4) seni kerajinan dan pariwisata, 5) agribisnis dan agroteknologi serta 6) bisnis dan manajemen.

Sekolah menegah kejuruan bidang studi pariwisata merupakan sekolah menegah kejuruan yang mendidik para siswanya untuk terampil dan menjadi tenaga kerja yang siap bekerja pada dunia pariwisata. Untuk menghasilkan siswa yang ahli dibidangnya yang siap bekerja sesuai dengan tututan dunia kerja maka diperlukan guru yang profesional dan memiliki kinerja yang sangat baik dalam menjalankan tugas sesuai dengan profesinya sebagai seorang tenaga pendidik. Hasil pendidikan yang baik menjadi tolak ukur bagi keberhasilan kinerja yang ditunjukkan guru. Keberhasilan guru dalam menjalankan tugasnya dapat dilihat dari hasil belajar yang diperoleh oleh siswa yang didik oleh guru tersebut. Salah satu alat yang dapat dijadikan ukuran untuk menilai keberhasilan siswa dalam belajar adalah nilai yang diperoleh oleh siswa dari setiap mata pelajaran yang diikutinya. Guru dikatakan berhasil mendidik ketika semua siswa yang didiknya mendapatkan nilai yang sangat memuaskan dari pelajaran yang diampunya.

Jika nilai semua siswa yang didik oleh guru dari mata pelajaran yang diampunya memperoleh nilai yang sangat memuaskan maka dapat dikatakan guru terbut memiliki kinerja yang sangat baik. Dalam hal ini yang dimaksud dengan kinerja adalah perilaku nyata yang ditampilkan setiap orang sebagai prestasi kerja yang dihasilkan dalam melakukan suatu pekerjaan sesuai dengan perannya dalam perusahaan (Rivai, 2013:549). Kinerja adalah tingkat keberhasilan seseorang atau kelompok orang dalam melaksanakan tugas dan tanggung jawabnya serta kemampuan untuk mencapai tujuan dengan standar yang telah ditetapkan.

Jika dikaitkan dengan kinerja guru maka kenerja guru merupakan hasil kerja yang ditunjukkan guru dalam melaksanakan tugas dan tanggung jawabnya sesuai dengan profesinya. Kinerja seseorang dapat ditingkatkan bila ada kesesuaian antara pekerjaan dengan keahliaannya. Untuk mengetahui keberhasilan kinerja perlu dilakukan evaluasi atau penilaian kinerja dengan berpedoman pada parameter dan indikator yang telah ditetapkan. Menurut Rachmawati (2013:18) menilai kualitas guru dapat ditinjau dari beberapa indikator yang meliputi: (1). Unjuk kerja, (2). Penguasaan materi, (3). Penguasaan 
profesional keguruan dan pendidikan, (4). Penguasaan cara-cara penyesuaian diri, (5). Kepribadian untuk melaksanakan tugas dengan baik.

Kinerja guru sangat penting untuk diperhatikan dan dievaluasi karena guru mengemban tugas profesional artinya tugas-tugas yang hanya dapat dikerjakan dengan kompetensi khusus yang diperoleh melalui program pendidikan. Guru mempunyai potensi yang cukup tinggi untuk berkreasi sebagai usaha meningkatkan kinerjanya. Namun usaha peningkatan kinerja guru tidak selalu berkembang dengan baik karena adanya pengaruh dari berbagai faktor yang muncul dari dalam pribadi guru maupun faktor dari luar pribadi guru itu sendiri.

Sebagaimana yang dikemukakan Anuraga (2006:56), bahwa faktor yang mempengaruhi kinerja adalah daya tarik pekerjaan, insentif/gaji, kemanan dan perlindungan kerja, pengetahuan, manajemen kelas, lingkungan dan suasana kerja, harapan pengembangan karir dalam pengembangan organisasi, perhatian dan kepemimpinan. Dengan mengetahui dan memahami secara mendalam tentang faktor yang berpengaruh terhadap kinerja guru maka dapat dicarikan alternatif pemecahannya sehingga faktor tersebut bukan menjadi hambatan bagi peningkatan kinerja guru ke arah yang lebih baik, karena kinerja dapat ditingkatkan dari waktu ke waktu.

Kompensasi finansial memang bukan satu-satunya faktor yang mempengaruhi kinerja guru. Tetapi kompensasi tetap diakui sebagai salah satu faktor penentu dalam meningkatkan kinerja. Apabila dikaitkan dengan evaluasi pekerjaan, maka seorang pekerja akan lebih semangat dan memaksimalkan pekerjaannya karena dihargai karyanya.
Kompensasi finansial yang diberikan pemerintah terhadap guru tidak perlu diragukan lagi. Hal ini dibuktikan dengan berbagai kebijakan yang diterapkan pemerintah untuk meningkatkan kesejahteraan guru. Sertifikasi guru adalah salah satu kebijakan yang dilakukan pemerintah untuk meningkatkan kesejateraan guru, dimana berdasarkan peraturan menteri pendidikan nasional no. 8 tahun 2007 tentang setifikasi guru, bagi guru yang telah bersertifikasi berhak mendapatkan tunjangan profesi sebesar satu bulan gaji pokok guru. Selain itu pemerintah setiap tahunnya selalu berupaya untuk meningkatkan gaji guru (melakukan penyesuaian dan menaikkan gaji guru).

Kompensasi finansial yang diberikan kepada guru akan sangat berpengaruh terhadap motivasi kerja guru. Kompensasi finansial yang diberikan pemerintah kepada guru saat ini sudah dapat dikatakan cukup baik. Dimana dalam hal ini pemerintah menentukan tingkat gaji guru dengan mempertimbangkan standar kehidupan normal yang memungkinkan guru bekerja dengan penuh motivasi. Karena terpenuhi atau tidaknya kebutuhan minimal kehidupan seorang guru dan keluarganya akan mempengaruhi motivasi kerja guru dan secara langsung maupun tidak langsung akan berpengaruh juga terhadap kinerja guru tersebut dalam menjalankan tugas dan tanggung jawabnya sebagai tenaga pendidik di sekolah.

Penelitian ini bertujuan untuk menjelaskan pengaruh kompensasi finansial (X1) terhadap motivasi kerja (X2), pengaruh kompensasi finansial (X1) terhadap kinerja guru (Y), pengaruh motivasi kerja (X2) terhadap kinerja guru (Y) dan pengaruh kompensasi finansil 
(X1) dan motivasi kerja (X2) terhadap kinerja guru (Y).

\section{Kinerja Guru}

Secara teori dan realita yang terjadi terdapat hubungan erat antara kinerja seseorang (individual performance) dengan kinerja lembaga (institutional performance). Jika seorang karyawan dalam sebuah intitusi mempunyai kinerja yang sangat baik maka secara langsung institusi tersebut juga mempunyai kinerja yang sangat baik sehingga apa yang menjadi tujuan institusi dapat terwujud. Kinerja seseorang karyawan dalam sebuah institusi akan lebih baik jika ia mempunyai keahlian (skill) atau kompetensi yang tinggi, bersedia bekerja karena digaji atau diberi upah sesuai dengan perjanjian, mempunyai harapan (expectation) masa depan lebih baik.

Kinerja merupakan hasil kerja yang dapat dicapai oleh seseorang atau sekelompok orang dalam suatu organisasi, sesuai dengan wewenang dan tanggung jawab masing-masing, dalam rangka upaya mencapai tujuan organisasi bersangkutan secara legal, tidak melanggar hukum sesuai dengan maupun etika. Istilah kinerja merupakan terjemahan dari Job Performance atau Actual performance (prestasi kerja atau prestasi sesungguhnya yang dicapai oleh seseorang) menurut Mangkunegara (2001:67).

Menurut pendapat Rivai, (2013:549) kinerja adalah perilaku nyata yang ditampilkan setiap orang sebagai prestasi kerja yang dihasilkan oleh karyawan sesuai dengan perannya dalam perusahaan. Berdasarkan pengertian di atas dapat dipahami bahwa kinerja merupakan hasil dari suatu perbuatan atau tindakan nyata, dalam rangka meningkatkan prestasi sesuai dengan tujuan yang ditetapkan berkaitan dengan tugas dan tanggung jawab yang dilakukan dalam suatu pekerjaan sesuai dengan profesi.

Berhubungan dengan profesi guru dapat dijelaskan bahwa guru adalah seorang tenaga profesional yang dapat menjadikan murid-muridnya mampu merencanakan, menganalisis dan menyimpulkan masalah yang dihadapi (Nurdin, 2005:62). Sedangkan Gager dan Berliner (1979:56) mengemukakan bahwa guru sebagai pengajar bertugas merencanakan pengajaran, melaksanakan pengajaran di kelas, dan mengevaluasi pengajaran.

Guru sebagai perencana pengajaran melakukan tugas-tugas sebagai berikut: (1) Merancang silabus. Mempersiapkan rencana pengajaran. (3) Menentukan langkah-langkah kegiatan belajar mengajar. (4) Merancang alokasi waktu dan (5) Memilih media. Untuk menjalankan tugas dan tanggung jawab secara profesional, kinerja guru merupakan suatu hal yang penting untuk ditingkatkan agar tujuan pendidikan dapat terwujud.

Menurut Rachmawati (2013:16) menjelaskan bahwa kinerja guru adalah kemampuan yang ditunjukkan oleh guru dalam melaksanakan tugas atau pekerjaannya, dimana kinerja dikatakan baik dan memuaskan apabila hasil yang dicapai sesuai dengan standar yang telah ditetapkan. Hal yang sama juga dikemukakan oleh Nana Sudjana (2004:19) juga menjelaskan bahwa kinerja guru sebagai pengajar dapat dilihat dari kemampuan atau kompetensinya melaksanakan tugas tersebut.

Berdasarkan pendapat-pendapat ini dapat diambil suatu kesimpulan bahwa kinerja guru merupakan hasil dari suatu 
perbuatan atau tindakan nyata, dalam rangka meningkatkan prestasi sesuai dengan tujuan yang ditetapkan berkaitan dengan tugas dan tanggung jawab yang dilakukan dalam suatu pekerjaan sesuai dengan profesi, dimana tugas seorang guru adalah merencanakan proses belajar mengajar, melaksanakan dan mengelola proses belajar mengajar, menilai kemajuan proses belaja mengajar dan menguasai bahan pelajaran.

Teori diatas juga menjelaskan begitu pentingnya kinerja guru untuk ditingkatkan karena kinerja ini memberikan pengaruh terhadap proses pembelajaran di sekolah. Namun usaha peningkatan kinerja guru tidak selalu berkembang dengan baik karena adanya pengaruh dari berbagai faktor yang muncul dari dalam pribadi guru dan faktor dari luar pribadi guru itu sendiri. Sebagaimana yang dikemukakan Anuraga (2006:56), bahwa faktor yang mempengaruhi kinerja adalah daya tarik pekerjaan, insentif/gaji, keamanan dan perlindungan kerja, pengetahuan, manajemen kelas, lingkungan dan suasana kerja, harapan pengembangan karir dalam pengembangan organisasi, perhatian dan kepemimpinan.

Menurut Marthis dan Jackson (2001:82) menyatakan banyak faktor yang mempengaruhi kinerja dari suatu perusahaan diantaranya perilaku kerja, karyawan, motivasi, dukungan yang diterima, keberadaan pekerjaan yang mereka lakukan, budaya organisasi dan hubungan mereka dengan organisasi.

Sedangkan Yamin (2010:129) menyatakan faktor yang mempengaruhi kinerja dapat yang berasal dari personal yaitu 1) pengetahuan, 2) keterampilan, 3) kemampuan, 4) kepercayaan diri, 5) motivasi, 6) komitmen. Menurut Rachmawati (2013:19) ada beberapa faktor yang mempengaruhi kinerja guru antara lain: a). Kepribadian dan dedikasi, b). Pengembangan profesi, c). Kemampuan mengajar, d). Antar hubungan dan komunikasi, e). Hubungan dengan masyarakat, f) Kedisiplinan, g) Kesejahteraan, h). Iklim kerja.

\section{Kompensasi Finansial}

Kompensasi merupakan segala sesuatu yang diterima para karyawan atau pekerja sebagai balas jasa untuk kerja mereka. Rivai (2013:741) menjelaskan bahwa kompensasi merupakan sesuatu yang diterima karyawan sebagai pengganti jasa mereka pada perusahaan. Sedangkan Wukir (2013:84) menyatakan bahwa kompensasi adalah suatu balas jasa atau imbalan yang diberikan kepada karyawan atas pekerjaan mereka. Kompensasi harus sesuai dengan jumlah dan kualitas pekerjaan. Sedangkan Sitohang (2007:220) menjelaskan bahwa kompensasi adalah pegaturan keseluruhan pemberian balas jasa bagi pegawai dan para manajer baik berupa finansial maupun barang dan jasa pelayanan yang diterima oleh setiap orang karyawan.

Kompensasi ini jika dikelola dengan baik akan membantu perusahaan atau organisasi mencapai tujuan, memperoleh serta menjaga karyawan dengan baik. Sebaliknya tanpa kompensasi yang cukup, karyawan yang ada sangat mungkin akan meninggalkan perusahaan akibat dari ketidakpuasan karyawan. Hal ini tentu memberikan pengaruh negatif terhadap kinerja karyawan di perusahaan atau institusi. Berkaitan dengan hal ini menurut Timpe (2000:66) insentif maupun gaji yang diberikan dapat memotivasi seseorang dalam bekerja. Apabila gaji/insentif yang diterima sesuai dengan jenis pekerjaan yang diembannya, maka hal ini akan 
mendorongnya untuk bekerja lebih baik. Sebaliknya rasa ketidakpuasan dalam pembayaran yang dirasakan kurang akan mengurangi kinerja.

Jika dikaitkan dengan profesi guru menurut Hasibuan (2005) kompensasi adalah semua pendapatan uang, barang langsung yang diterima guru sebagai imbalan atau jasa yang diberikan sekolah. Menurut Rivai (2013:741) kompensasi finansial terdiri dari kompensasi tidak langsung dan kompensasi langsung. Kompensasi langsung terdiri dari pembayaran karyawan dalam bentuk upah, gaji, bonus, atau komisi. Kompensasi tidak langsung, atau benefit terdiri dari semua pembayaran yang tidak tercakup dalam kompensasi finansial langsung yang meliputi liburan, berbagai macam asuransi, jasa seperti perawatan anak atau kepedulian keagamaan, dan sebagainya. Jadi kompensasi finansial dalam penelitian ini adalah balas jasa yang diterima guru dalam bentuk finansial (uang) terkait dengan pelaksanaan tugas dan tanggung jawabnya di sekolah dalam jangka waktu tertentu.

\section{Motivasi Kerja}

Motivasi merupakan seperangkat alasan dalam melakukan suatu tindakan tertentu. Motivasi dapat didefinisikan sebagai proses yang menjelaskan intensitas, arah dan ketekunan seseorang dalam melakukan usaha untuk mencapai tujuannya. Motivasi seseorang bergantung kepada seberapa kuat motif mereka (Wukir, 2013:115). Lebih lanjut Rivai (2013:837) menjelaskan bahwa motivasi adalah serangkaian sikap dan nilai-nilai yang mempengaruhi individu untuk mencapai hal yang spesifik sesuai dengan tujuan individu. Sikap dan nilai tersebut merupakan sesuatu yang invisible yang memberikan kekuatan untuk mendorong individu bertingkah laku dalam mencapai tujuan. Dorongan tersebut terdiri dari dua komponen, yaitu: arah perilaku (kerja untuk mencapai tujuan), dan kekauatan perilaku (seberapa kuat usaha individu dalam bekerja).

Anoraga (2006:87) menyatakan motivasi adalah daya pendorong yang mengakibatkan seseorang mau rela untuk menggerakkan kemampuan dalam bentuk keahlian atau keterampilan, tenaga, dan waktunya untuk melaksanakan berbagai kegiatan yang menjadi tanggung jawabnya. Barelson dan Steiner dalam Sastrohadiwiryo (2002:267), mendefinisikan motivasi sebagai " all those inner striving conditions variously described as wishes, desire, needs, drives, and the like" dari pernyatan ini dapat diartikan motivasi sebagai keadaan jiwa dan sikap mental manusia yang memberikan energi, mendorong kegiatan atau menggerakkan dan mengarahkan atau menyalurkan perilaku kearah mencapai kebutuhan yang memberi kepuasan atau mengurangi ketidak seimbangan.

Menurut Sardiman (2007:89), jenis-jenis motivasi terbagi atas dua jenis yaitu motivasi instrinsik dan ekstrinsik. Motivasi instrinsik adalah motif-motif yang menjadi aktif atau berfungsinya tidak perlu dirangsang dari luar, karena dalam diri setiap individu sudah ada dorongan untuk melakukan sesuatu. Sedangkan motivasi ekstrinsik adalah motif-motif yang aktif dan berfungsinya karena adanya perangsang dari luar.

Motivasi kerja seseorang dalam bekerja dipengaruhi oleh berbagai faktor yang bersifat internal maupun ekternal. Sebagaimana yang dikemukakan oleh Rivai (2013:838) beberapa aspek yang berpengaruh terhadap motivasi kerja yakni: rasa aman dalam bekerja, 
mendapatkan gaji yang adil dan kompetitif, lingkungan kerja yang menyenangkan, penghargaan atas prestasi kerja dan perlakuan yang adil dari manajemen. Sejalan dengan apa yang telah dikemukakan dari pendapat di atas Siagian (2002:40) mengatakan bahwa faktor-faktor yang mempengaruhi motivasi kerja seseorang mencapai keberhasilan tujuan organisasi dipengaruhi oleh beberapa faktor yaitu berupa: harapan, keinginan, cita-cita, dan berbagai jenis kebutuhannya

\section{Hipotesis}

1. Diduga adanya pengaruh yang signifikan kompensasi finansial (X1) terhadap motivasi kerja (X2)

2. Diduga adanya pengaruh yang signifikan kompensasi finansial (X1) terhadap kinerja guru (Y)

3. Diduga adanya pengaruh yang signifikan motivasi kerja (X2) terhadap kinerja guru $(\mathrm{Y})$

4. Diduga adanya pengaruh yang signifikan kompensasi finansial (X1) dan motivasi kerja (X2) terhadap kinerja Guru (Y)

\section{METODE PENELITIAN}

Penelitian ini merupakan penelitian penjelasan (explanatory research) dengan latar belakang untuk menjelaskan pengaruh antar variabel yang diuji dengan menggunakan hipotesis yang telah ditetapkan. Populasi dalam penelitian ini adalah seluruh guru pada SMK Negeri Pariwisata di kota Padang yang berjumlah 117 orang. Untuk menentukan banyaknya sampel dari suatu populasi, jika ukuran populasi diketahui maka digunakan rumus Slovin, dengan bantuan rumus Slovin diperoleh 90 orang guru yang dijadikan sampel dalam penelitian ini.
Dalam penelitian ini data dikumpulkan melalui kuesioner yang diberikan kepada responden, data yang telah dikumpulkan diolah serta dianalisis secara statistik dengan bantuan analisis parametrik menggunakan SPSS ( Statistial Package for Social Science). Teknik analisis data yang digunakan adalah analisis jalur (Path Analisys). Sejalan dengan tujuan penelitian yaitu untuk menganalisis tentang pengaruh variabel penyebab terhadap variabel akibat baik secara langsung maupun tidak langsung. Pada dasarnya jalur (path) adalah koefisien regresi yang distandarkan yaitu koefisien regresi yang dihitung dari basis data yang telah diset dalam angka baku atau Z-score (data yang diset dengan nilai rata-rata $=0$ dan standar deviasi $=1$ ).

\section{E. Hasil Dan Pembahasan}

Berdasarkan tabel 1 diatas hasil analisis menunjukkan bahwa variabel kompensasi finansial berpengaruh signifikan terhadap motivasi kerja guru SMK Negeri Pariwisata di Kota Padang. Hal ini ditunjukkan oleh nilai signifikan probability $=0.000<0.050$ dengan koefisien jalur 0.717. Dari analisis tersebut dapat disimpulkan terdapat pengaruh positif dan signifikan antara kompensasi finansial terhadap motivasi kerja guru SMK Negeri Pariwisata di Kota Padang, dimana semakin meningkat kompensasi finansial guru maka akan semakin meningkat pula motivasi kerja guru. Hal ini membuktikan bahwa hipotesis pertama dalam penelitian dapat dibuktikan.

Sedangkan besarnya pengaruh variabel lain terhadap motivasi kerja guru yang tidak dibahas dalam penelitian ini adalah sebesar 0.697 Berdasarkan hasil analisis dari tabel 2 diatas diperoleh $\mathrm{F}$ sebesar 70.493 dengan signifikan sebesar $0.000<0.050$. Hal ini berarti bahwa 
secara bersama-sama kompensasi finansial dan motivasi kerja berpengaruh signifikan terhadap kinerja guru SMK Negeri Pariwisata di Kota Padang. Hal ini dapat digunakan untuk menguji hipotesis keempat dalam pnelitian ini. Kemudian dilanjutkan dengan uji secara parsial dari hasil penelitian diperoleh koefisien jalur 0.332 dengan signifikan $0.001<0.050$, hal ini berarti bahwa kompensasi finansial berpengaruh signifikan terhadap kinerja guru SMK Negeri Pariwisata di Kota Padang. Ini membuktikan bahwa hipotesis kedua dalam penelitian dapat dibuktikan.

Untuk koefisien jalur 0.514 dengan signifikan 0,000, hal ini berarti bahwa motivasi kerja berpengaruh signifikan terhadap kinerja guru SMK Negeri Pariwisata di Kota Padang, yang berarti hipotesis ketiga dalam penelitian ini dapat dibuktikan. Sedangkan pengaruh variabel lain atau peran faktor lain yang tidak diteliti dalam penelitian ini adalah sebesar 0.462 atau $46.2 \%$. Berdasarkan hasil analisis data pada sub struktur 1 diketahui bahwa besarnya pengaruh kompensasi finansial terhadap motivasi kerja guru SMK Negeri Pariwisata dikota Padang sebesar 51\%. Dari hasil penelitian juga juga diperoleh bahwa besarnya pengaruh kompensasi finansial secara langsung terhadap kinerja guru SMK Negeri Pariwisata di Kota Padang adalah sebesar $11.02 \%$. Secara tidak langsung besarnya pengaruh kompensasi finansial terhadap kinerja guru SMK Negeri Pariwisata di Kota Padang adalah sebesar $12.23 \%$. Untuk variabel motivasi kerja secara langsung memberikan pengaruh sebesar $26.41 \%$ terhadap kinerja guru SMK Negeri Pariwisata di Kota Padang. Sedangkan besarnya pengaruh variabel lain yang tidak diteliti dalam penelitian ini terhadap kinerja guru
SMK Negeri Pariwisata di Kota Padang sebesar $46.2 \%$

Hasil penelitian ini memperlihatkan bahwa motivasi kerja memiliki kontribusi pengaruh yang lebih besar terhadap kinerja guru dibandingkan dengan kompensasi finansial yang diterima guru. Sedangkan secara langsung kompensasi finansial memiliki pengaruh sebesar $51 \%$ terhadap motivasi kerja guru SMK Negeri Pariwisata di Kota Padang. Hal ini berarti dengan meningkatnya kompensasi finansial yang diterima guru maka akan meningkat pula motivasi kerja guru yang secara langsung maupun tidak langsung berpengaruh signifikan terhadap kinerja guru SMK Negeri Pariwisata di Kota Padang.

\section{PEMBAHASAN}

Berdasarkan hasil analisis jalur dan hasil pengujian hipotesis pertama, diketahui bahwa kompensasi finansial berpengaruh signifikan terhadap motivasi kerja guru akuntansi SMK Negeri Pariwisata di Kota Padang. Artinya dengan adanya peningkatan kompensasi finansial maka akan dapat meningkatkan motivasi kerja guru. Hal ini sejalan dengan apa yang dikemukakan oleh Rivai (2013:838) beberapa aspek yang berpengaruh terhadap motivasi kerja yakni: rasa aman dalam bekerja, mendapatkan gaji yang adil dan kompetitif, lingkungan kerja yang menyenangkan, penghargaan atas prestasi kerja dan perlakuan yang adil dari manajemen. Sejalan dengan apa yang telah dikemukakan dari pendapat di atas Siagian (2002:40) mengatakan bahwa faktor-faktor yang mempengaruhi motivasi kerja seseorang mencapai keberhasilan tujuan organisasi dipengaruhi oleh beberapa faktor yaitu berupa: harapan, keinginan, cita-cita, dan 
berbagai jenis kebutuhannya. Hasil penelitian ini sejalan dengan penelitian Agiel Puji Damayanti (2013:165), adanya pengaruh positif kompensasi dengan motivasi kerja.

Dengan adanya peningkatan kompensasi finansial yang diterima guru maka secara langsung akan memberikan pengaruh terhadap motivasi kerja guru, dimana besarnya pengaruh kompensasi finansial terhadap motivasi kerja dari hasil penelitian diperoleh sebesar $51 \%$ dan sisanya dipengaruhi oleh variabel lain yang tidak diteliti dalam penelitian ini.

Hasil pengujian analisis jalur hipotesis kedua diperoleh nilai signifikan $0.000<0.050$ secara statistik signifikan. Koefisien jalur variabel kompensasi finansial $\left(\mathrm{X}_{1}\right)$ dan motivasi kerja $\left(\mathrm{X}_{2}\right)$ menunjukkan angka yang positif, hal ini berarti kompensasi finansial dan motivasi kerja memiliki pengaruh yang signifikan terhadap kinerja guru pada $\alpha=0,05$. Hasil penelitian ini sesuai dengan teori yang dikemukakan Timpe (2000:66) bahwa insentif maupun gaji yang diberikan dapat memotivasi seseorang dalam bekerja. Pendapat yang sama dikemukakan Rivai (2013:741) yang menyatakan jika dikelola dengan baik, kompensasi akan membantu perusahaan untuk mencapai tujuan serta memperoleh, memelihara, dan menjaga karyawan dengan baik. Sebaliknya akibat dari rasa ketidakpuasan dalam pembayaran yang dirasakan kurang akan mengurangi kinerja. Hasil penelitian ini juga sejalan dengan penelitian yang telah dilakukan oleh Nurul Astuty Yensy. B (2010:40) hasil penelitiannya menyatakan bahwa kompensasi memberikan pengaruh positif terhadap kinerja guru.
Hasil analisis hipotesis 3 diperoleh koefisien jalur 0.514 dengan signifikansi $0.000<0.050$ yang berarti bahwa semakin meningkat motivasi kerja guru maka akan meningkat pula kinerja guru dalam melaksanakan tugasnya. Hasil penelitian ini sesuai dengan teori Marthis dan Jackson (2001:82) yang menyatakan banyak faktor yang mempengaruhi kinerja dari suatu perusahaan diantaranya perilaku kerja, karyawan, motivasi, dukungan yang diterima, keberadaan pekerjaan yang mereka lakukan, budaya organisasi dan hubungan mereka dengan organisasi.

Berdasarkan analisis jalur semua variabel eksogenus (kompensasi finansial, kompetensi profesional, dan motivasi kerja berpengaruh signifikan terhadap variabel endogenus (kinerja guru) baik secara langsung maupun tidak langsung.

\section{PENUTUP}

1. Kompensasi finansial berpengaruh signifikan terhadap motivasi kerja guru SMK Negeri Pariwisata di Kota Padang. Besarnya pengaruh kompensasi finansial terhadap motivasi kerja guru sebesar $51 \%$. Hal ini berarti dengan adanya peningkatan kompensasi finansial guru maka akan meningkatkan motivasi kerja guru.

2. Kompensasi finansial berpengaruh signifikan terhadap terhadap kinerja guru SMK Negeri Pariwisata di Kota Padang. Besarnya pengaruh kompensasi finansial terhadap kinerja guru secara langsung sebesar $11.02 \%$, sedangkan besarnya pengaruh kompensasi finansial secara tidak langsung terhadap kinerja guru sebesar 12.23\%. Hal ini mengindikasikan bahwa dengan 
kompensasi finansial yang memuaskan baik secara langsung maupun tidak langsung akan meningkatkan kinerja guru SMK Negeri Pariwisata di Kota Padang dalam melaksanakan tugas dan tanggung jawabnya sebagai seorang tenaga pendidik di sekolah.

3. Motivasi kerja berpengaruh signifikan terhadap kinerja guru SMK Negeri Pariwisata di Kota Padang, dimana besarnya pengaruh tersebut secara langsung sebesar $26.41 \%$.

4. Kompensasi finansial dan motivasi kerja secara bersama-sama berpengaruh terhadap kinerja guru SMK Negeri pariwisata di Kota Padang. Pengaruh kedua variabel ini dalam penelitian terhadap kinerja berpengaruh secara langsung maupun tidak langsung. Hal ini mengindikasikan tinggi rendahnya kompensasi finansial, dan motivasi kerja berpengaruh terhadap kinerja guru.

\section{DAFTAR PUSTAKA}

10.22202/economica.2016.v4.i2.628

Anoraga, Pandji. 2006. Psikologi Kerja. Jakarta: Rineka Cipta.

Damayanti, Puji Agiel. 2013. Pengaruh Kompensasi Dan Motivasi Kerja Terhadap Karywan Perusahaan Daerah Air Minum (PDAM) Surakarta. .Jupe UNS Vol 2 No 1.

Depdiknas. 2005. Undang-undang No

14 Tahun 2005 Tentang Guru dan Dosen. Jakarta. Depdiknas.

Hamzah, B. Uno. 2007. Profesi Kependidikan. Jakarta: Bumi Aksara.

Mangkunegara, Anwar. 2001. Manajemen Personalia dan Sumber
Daya Manusia, Edisi 2. Yogyakarta: BPFE.

Mathis, Robert L. dan John H. Jackson. Alih Bahasa Jimmy Sadeli dan Bayu Prawira Hie. 2001. Manajemen Sumber Daya Manusia. Jakarta: Salemba Empat.

Mulyasa,E. 2012. Standar Kompetensi dan Sertifikasi Guru. Bandung: PT Remaja Rosdakarya.

Rachmawati, Tutik. 2013. Penilaian Kinerja Profesi Guru Dan Angka Kreditnya. Yogyakarta: Gava Media. Riduwan. 2012. Cara Menggunakan Dan Memakai Path Analysi. Bandung: Alfabeta.

Rivai, Veithzal. 2013. Manajeman Sumber Daya Manusia Untuk Perusahaan. Edisi Kedua. Cetakan Kelima. Jakarta: PT Rajagrafindo Persada.

Sastrohadiwiryo, Siswanto. 2002. Manajemen Tenaga Kerja Indonesia. Jakarta: Rineka Cipta.

Siagian, Sondang P. 2002. Teori Motivasi dan Aplikasinya. Jakarta: PT. Rineka Cipta.

Sunarsono dan Sumadi. 2007. Analisis Faktor Yang Berpengaruh Terhadap Kinerja Guru Sekolah Menegah Kejuruan. Jurnal Manajemen Sumberdaya Manusia Vol.2 No. 1.

Susanto, Hary. 2012. Faktor-Faktor Yang Mempengaruhi Kinerja Guru Sekolah Menengah Kejuruan. http:// Journal. UNY. AC. id. diakses 2 Okteober 2013.

Timpe, Dale. 2000. Sari Ilmu dan Seni Manajemen Bisnis. Elek Media.

Udiyono. 2011. Pengaruh Kompetensi Profesional Dan Keikutsertaan Dalam Forum Ilmiah Serta Karya Pengembangan Profesi Terhadap Kinerja Guru. Jurnal Magistra No. 76 Th. XXIII. 
Yamin, Martinis. 2010. Standarisasi Kinerja Guru. Jakarta: Gaung Persada Press.

Yensi B, Nurul Astuty. 2010. Pengaruh Kompensasi Dan Motivasi Terhadap
Kinerja Guru Di SMA Ngeri 2 Arga Makmur Bengkulu Utara. Jurnal Pendidikan Triadik Volume 13 No 1. 